\title{
P-6 \\ NILE DELTA OFFSHORE-WEST DELTA DEEP MARINE CONCESSION - EVOLUTION OF THE PRINCIPAL TECTONICS LINEAMENTS OF THE AREA - ROSETTA WRENCH FAULT ASSEMBLAGE
}

RAFFAELE BUONAGURO and ANDREA SITTA

Edison Gas SpA., Foro Buonaparte 31, 20121 Milan, Italy

\begin{abstract}
The WEST DELTA DEEP MARINE (WDDM) concession is located in the Nile Delta offshore, $70 \mathrm{Km}$ off the Egyptian coast.

An aggressive exploration activity was carried out by British Gas and Edison Gas during the last five years, infact, more than $5000 \mathrm{Km} 2 \mathrm{D}$ seismic lines and $1.500 \mathrm{Sqkm}$ 3D seismic surveys had been acquired allowing the drilling of 7 exploratory and appraisal wells.
\end{abstract}

The WDDM concession is affected by two main faults that are still active in the area (fig.1):

- The SW-NE-oriented Rosetta fault, representing part of an important regional structural element named "Qattara-Rosetta-Eratosthenes" (left-lateral oblique-slip, by Abdel, El Barkooky, Gerrits et Al.,Shell Egypt Deepwater B.V., 2000);

- The WSW-ENE-oriented NDOA fault, which throws down to the south part of the NDOA anticline.

There is also a minor.NW-SE oriented normal faults trend, located NW of the main Rosetta fault, cutting the upper Miocene level and stopping in the basal Pliocene.

On the basis of available bibliography concerning the area (see: Khalil \& Barsoum, IEOC,1998; Mahmoud \& El Barkooky, 1998), most likely the main tectonic events that affected the area were originated during Early Mesozoic period with extensional movements along. different patterns of fault (E-W; NE-SW) due to the opening of Neo-Thethys.

The pattern of regional faults continue deeply towards the SW into the African craton: it is assumed that from Pre-Cambrian age it worked as a system of "en echelon" left lateral megashear system and that, from Paleozoic, it also started to be a very important paleogeographic boundary.

The phase referred to as Early Upper Senonian - Early Tertiary is dominated by transpressive faults (ENE-WSW oriented) producing asymmetric folds with high angle reverse faults and thrust faults (north vergent).

In the Early - Upper Tertiary period transtensive movements took place along E-W E-NE axis causing reactivation of pre-existing E-NE faults as high angle normal faults. The Suez rifting started and created a new fault pattern $\mathrm{NW}$-oriented.

The interpretation of the recent 3D seismic data shows the existence of a new transpressive phase ending in the Middle Pliocene. This phase has generated asymmetric anticlines (NDOA 
structure, ENE-WSW oriented) wich are associated with reverse high angle faults (south vergent) ending towards the Rosetta fáult:

The NDOA anticline affects the lower and middle Pliocene sequence also folding the Pliocene deep water slope channel systems and changing their natural slope towards the north (see figs.2 and 3).

From Middle Pliocene to the present time the final extensional phase take place along the NESW (Rosetta) and ENE-WSW (NDOA) faults took place, cut the deep water slope channel systems and cause the sliding and slumping of big parts of sedimentary sequences, mud diapirism and steep slopes on the sea bottom. 


\section{ISOCHRONES TWT (sec.) NEAR TOP UPPER MIOCENE}

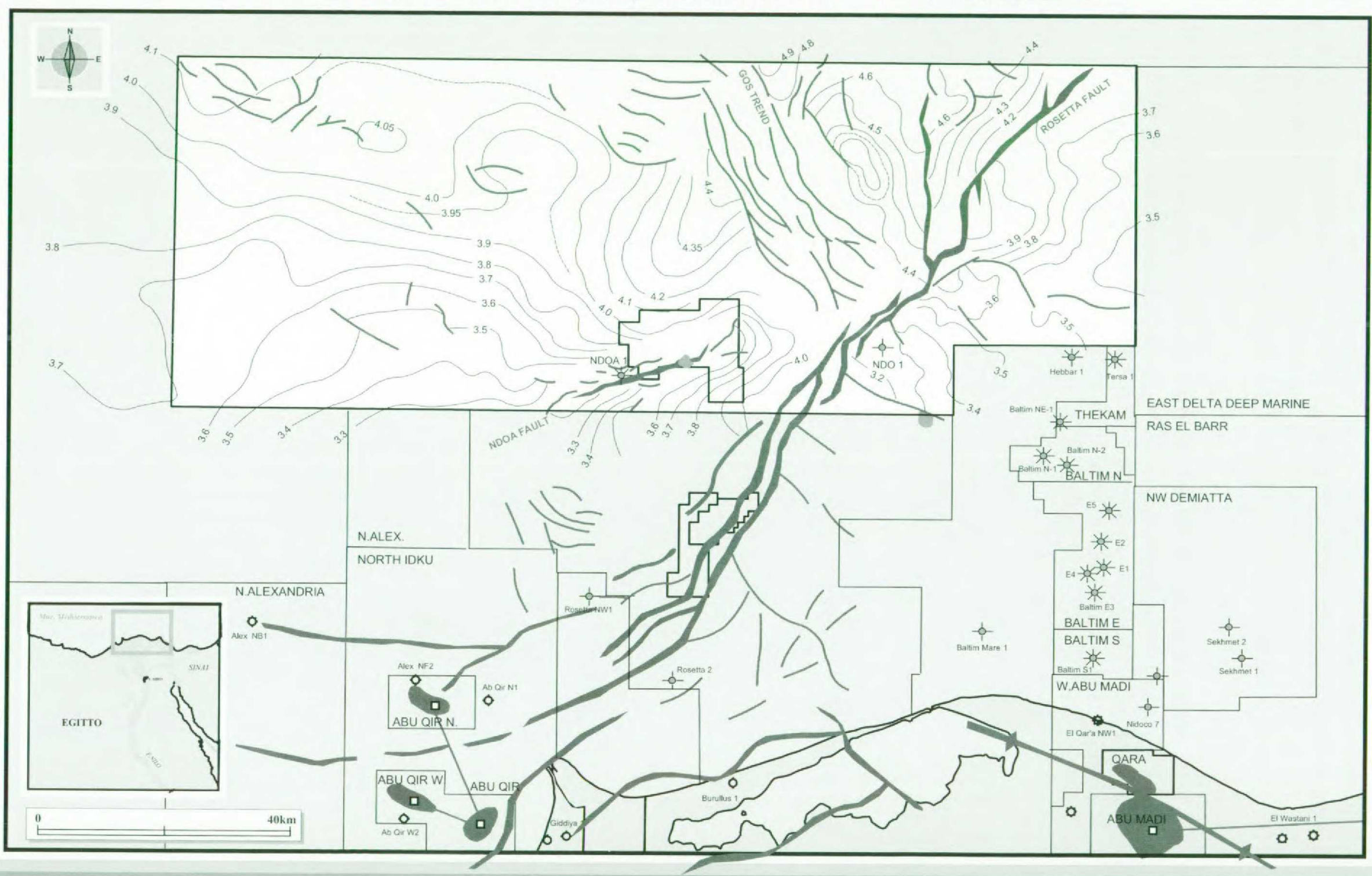


AMPLITUDE ANOMALY MAP OF A PLIOCENE SLOPE CHANNEL CUT BY RECENT FAULTS

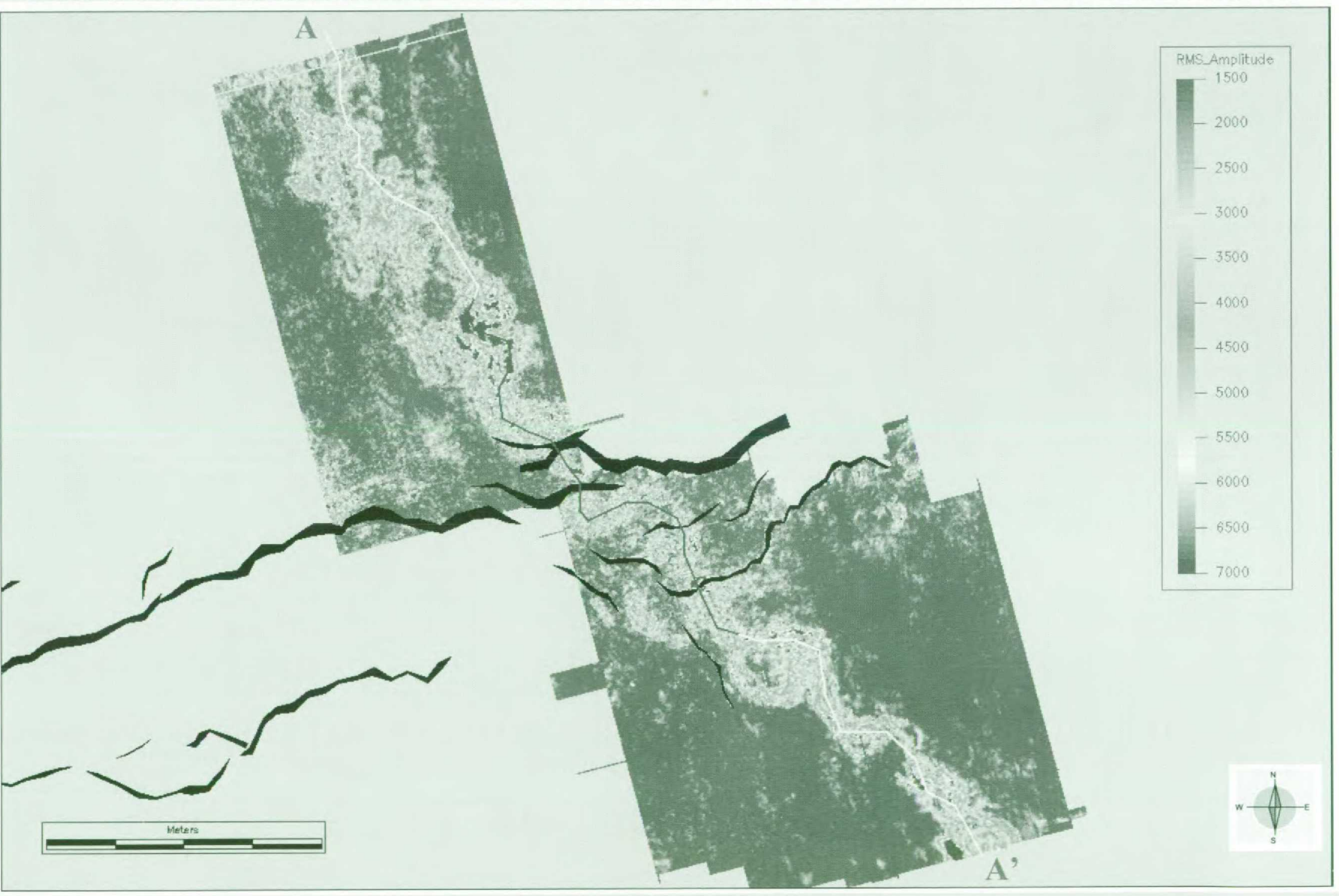




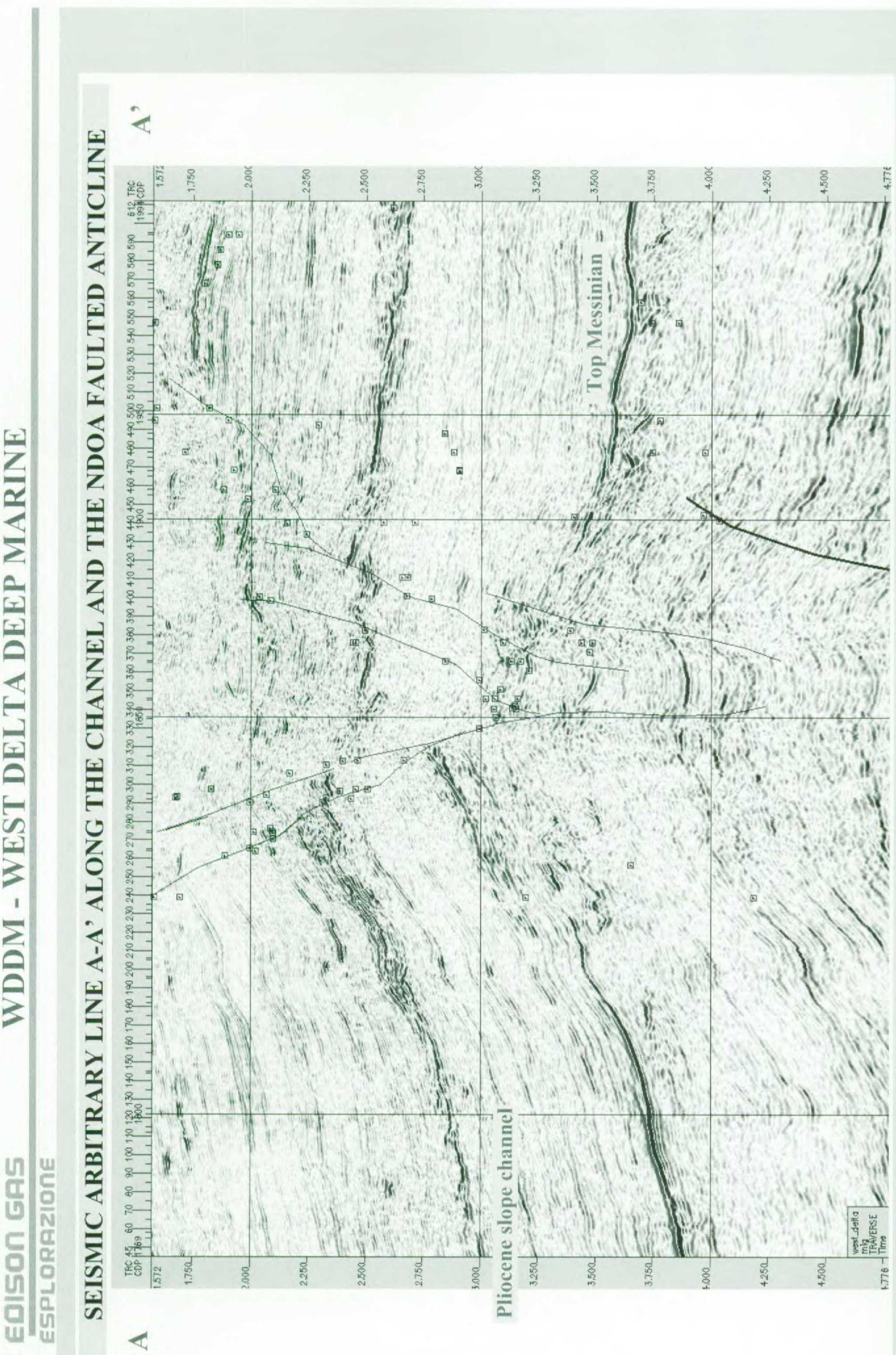

